\title{
Attitudes towards open access: A meta-synthesis of the empirical literature
}

\author{
Aspasia Togia* and Stella Korobili \\ Department of Library Science and Information Systems, ATEI of Thessaloniki, Thessaloniki, Greece
}

\begin{abstract}
The aim of the present study is to report the results of a meta-synthesis of the empirical literature on scholars' attitudes towards Open Access (OA) journals. A total of 15 articles published in scholarly journals since 2002 (when the Budapest Open Access Initiative was released) were included in the study and five major themes emerged from their examination and analysis. The literature indicates that attitudes and perceptions of OA are varied across countries and across disciplines. Free access, which is perceived to facilitate wider dissemination of research outputs, is a strong incentive for publishing in OA. However, quality and reputation are the most important factors in selecting a journal and take priority over the availability of free access. Although OA is perceived to have many advantages over the traditional publication model, it raises some concerns too, especially in regard to the author-pays model, the quality of peer-review and the impact of the journals.
\end{abstract}

Keywords: Open access, attitudes, scholars, authors, meta-synthesis

\section{Introduction}

Since their appearance in the 17th century, scholarly journals have been the main vehicle for the dissemination of scientific knowledge. Researchers publish the results of their activities for a number of reasons: to expand the knowledge in their subject field, to contribute towards solving problems or to establish their reputation [20]. On the other hand, access of scientists and academics to scientific literature is essential for upgrading their knowledge, designing new research studies and writing research papers. Scholars have always been seeking efficient ways for communicating their thoughts to the larger possible audience and the Open Access (OA) publishing model has the potential to meet this challenge, by making scientific information free for anyone to access. Open Access, as it is defined by the Budapest Open Access Initiative [6], is the free availability of scientific research publications, permitting users to read, download, copy, distribute, print, search, or link to the full texts of these publications without financial, legal or technical barriers. The concept of Open Access is not a new one, but it has really gained more attention in the last decade, mainly because it has begun to gain the support of governments, universities and funding agencies [1,14].

The Open Access movement has many supporters within the scholarly community, partly due to the growing dissatisfaction with traditional publishing models. As Allen [1] points out the combination of three important factors encouraged experimentation with alternative publishing models: escalating costs of scientific journals; objection to a model which restricts access to the results of publicly funded results; and Internet technology which allows widespread dissemination of information. On the other hand, opponents of OA raise serious concerns and point out several problems associated with the idea of

\footnotetext{
*Corresponding author. E-mail: aspatogi@ libd.teithe.gr.
} 
making all scholarship available for free [2]. In recent years a number of efforts to publish OA journals on a larger scale have emerged [4] and quite a few studies on authors' opinions and perceptions of OA have been published. This study reports the results of a meta-synthesis of the empirical literature on the attitudes of scholars towards OA journals. In an effort to make a contribution to the international literature on OA publishing, it synthesizes and analyzes the recent articles as collective body of literature.

\section{Methodology}

A qualitative method, known as meta-synthesis, has been employed in order to systematically analyze and synthesize the findings of previous studies on scholars' attitudes towards OA. Meta-synthesis was advanced by Bair and Haworth [3] in an effort to develop a comprehensive understanding of doctoral student attrition and retention. As a method for the integration of multiple research studies on a specific topic, meta-synthesis is related to, though distinct from, meta-analysis and meta-ethnography. Whereas meta-analysis is applied to quantitative studies, and meta-ethnography is applied to qualitative studies, meta-synthesis "synthesize findings from a combination of both qualitative and quantitative studies" [3, p. 485]. Meta-synthesis is a qualitative research methodology, since it is not possible to synthesize data from both qualitative and quantitative studies, due to the absence of a common metric. Its aim is to integrate, compare and analyze in a constructivist way many previously unrelated studies, allowing interpretive themes to emerge from the synthesis. Through this method, the results from the literature were synthesized, in order to identify key themes on attitudes towards OA publishing and understand these emerging themes in relationship to each other.

The studies used in this meta-synthesis met certain selection criteria: (i) they addressed scholars' attitudes and perceptions about OA journals; (ii) they reported the results of empirical research; (iii) they were full length articles published in peer-review journals; (iv) they were published between 2002 (when the Budapest Open Access Initiative was released) and 2013; (v) they were written in English. In December 2013 literature searches were performed in LISA and LISTA databases as well as in Google Scholar. In addition, the authors conducted ancestral searches of the reference lists of the articles retrieved through the database searches. Titles and abstracts were screened for relevance by the one of the two authors. The full texts of potentially relevant articles were assessed independently by the two authors and disagreements were resolved by discussion. Studies that were identified but not included in the sample were removed for one or more of the following reasons: (i) the study could not be considered a research article (it did not report use of specific research methodology neither it presented specific findings); (ii) the study examined the attitudes towards OA publishing from the perspective of publishers or librarians; (iii) the research was concerned with open access venues other than journals, e.g., institutional repositories; (iv) the study dealt with one specific aspect of OA, e.g., copyright; and (v) the full text of the study could not be obtained. This procedure resulted in a total of 15 articles which met the selection criteria. After the studies were gathered, they were read and summarized, and the following categories of information were noted: (i) author(s) and date of the study; (ii) national origin of the population surveyed; (iii) research objectives; (iv) participants; (v) research design; (vi) data collection instrument(s); (vii) major results. In the next step statements that explicitly described issues relevant to the attitudes towards OA journals were identified within each article. Using the QSR NVivo software package, interesting ideas were coded in a systematic way across the entire set of articles, and data relevant to each code were collated. The process of coding was part of the analysis, as data were organized into meaningful groups. After all data from the articles had been initially coded and collated, codes were 
analyzed and sorted into emergent themes. These themes represent the content of the entire set of articles examined. Theme identification followed an inductive approach, and codes were developed without adhering to a predetermined coding plan or the investigators' theoretical assumptions.

\section{Results}

The research objectives, participants, research design and the main findings of each study are presented in Table 1. The majority of the studies employed quantitative methods to collect and analyze data: ten of them were questionnaire based surveys and one used interviews to collect survey data. Two studies used qualitative approaches and other two employed mixed methods. Qualitative data were gathered through interviews, while a combination of interviews and questionnaires was used in the mixed methods studies. Five broad themes emerged from the analysis of the empirical literature.

\subsection{Theme 1: Awareness and experience of OA journals}

Findings are mixed with respect to awareness of OA journals. Some studies $[7,10,11,19,22]$ reported low levels of knowledge of the OA publishing model and the issues involved in it. In Gul, Shah and Baghwan's study [10] it was established that the majority of the respondents were aware of only two journals in their field, while in Coonin's study [7] the most popular answer to a question regarding how respondents became aware of OA was "first I've heard of it". On the contrary, in other studies [16,23,24, 26,27] a significant percentage of the respondents were aware of OA publishing and the existence of OA journals. Even in these cases, however, there is evidence of unfamiliarity or confusion with the "authorpays" model [24] and with some features of OA, such as the open peer-review or the ability to attach supplementary data to the articles journals [18]. According to Nicholas, Huntington and Rowlands [19] researchers from the US, Australasia and Western Europe were more likely to report knowing nothing about OA, while researchers from Eastern Europe, South America and Asia were more likely to report awareness. The authors explained this difference by supposing that scholars based in countries with a strong publishing system do not need to know about alternative models. Hernadez-Borges et al. [11] and Sanchez-Tarrago and Fernandez-Molina [22] attributed the relatively low levels of knowledge among Spanish-speaking scholars to the fact that OA initiatives appeared initially in English-speaking settings. Colleagues seem to play an essential role in raising OA awareness [7,10,16,18,22,26]. Self-knowledge is another common source of awareness $[7,16,18,22,26]$. Other sources of awareness are funding agencies $[7,10]$ and professional societies [7], while evidence about the role of the library is contradictory $[7,10$, $22,26]$.

A consistent finding of research in this area is the small number of authors actually publishing in OA journals. A number of researchers have found very low rates of publication in OA venues $[10,17,19,22-$ 24,27]. The most cited reasons for not publishing in OA journals were lack of familiarity with this type of publication and with methods for identifying OA journals to publish in [22,24], economic constraints associated with the author-pays model [22], and perceptions that OA publications are of poor quality and not widely read [24]. Nicholas, Huntington and Rowlands [19] found that scholars' location was associated with the use of OA journals as a medium for research dissemination. The authors commented that low publication rates were observed in locations which had a poor commitment to OA publishing. 
Table 1

The studies included in the meta-synthesis

\begin{tabular}{|c|c|c|c|c|c|c|}
\hline Author(s) & Population & $\begin{array}{l}\text { Research } \\
\text { objectives }\end{array}$ & Participants & $\begin{array}{l}\text { Research } \\
\text { design }\end{array}$ & $\begin{array}{c}\text { Data collection } \\
\text { instrument }\end{array}$ & Main results \\
\hline Coonin, 2011 & US & $\begin{array}{l}\text { To explore publishing } \\
\text { practices and } \\
\text { perceptions about OA } \\
\text { publishing }\end{array}$ & $\begin{array}{l}1,293 \text { business } \\
\text { faculty }\end{array}$ & Quantitative & Questionnaire & $\begin{array}{l}\text { Limited awareness of OA } \\
\text { journals. Low levels of } \\
\text { self-archiving. Confusion } \\
\text { regarding the issue of electronic } \\
\text { journal versus print publishing. }\end{array}$ \\
\hline $\begin{array}{l}\text { Gul, Shah and Baghwan, } \\
2010\end{array}$ & Kashmir & $\begin{array}{l}\text { To explore experience, } \\
\text { attitudes and perceptions } \\
\text { about the OA movement. }\end{array}$ & $\begin{array}{l}84 \text { science and } \\
\text { social sciences } \\
\text { faculty }\end{array}$ & Quantitative & Questionnaire & $\begin{array}{l}\text { The concept of OA is still in the } \\
\text { early stages. Differences in } \\
\text { publishing practices between } \\
\text { disciplines. }\end{array}$ \\
\hline $\begin{array}{l}\text { Hernadez-Borges et al., } \\
2006\end{array}$ & Spain & $\begin{array}{l}\text { To evaluate familiarity } \\
\text { with OA publishing and } \\
\text { attitudes towards the } \\
\text { author-pays model }\end{array}$ & $\begin{array}{l}100 \text { authors of } \\
\text { articles in } \\
\text { PubMed }\end{array}$ & Quantitative & Questionnaire & $\begin{array}{l}\text { Low awareness about OA } \\
\text { publishing model. Respondents } \\
\text { clearly rejected author fees due to } \\
\text { lack of funding and knowledge } \\
\text { about the prestige or reputation of } \\
\text { OA journals. }\end{array}$ \\
\hline $\begin{array}{l}\text { Ivwighreghweta and } \\
\text { Onoriode, } 2012\end{array}$ & Nigeria & $\begin{array}{l}\text { To examine the extent of } \\
\text { researchers' } \\
\text { appreciation of OA } \\
\text { publishing }\end{array}$ & $\begin{array}{l}140 \text { university } \\
\text { lecturers }\end{array}$ & Quantitative & Questionnaire & $\begin{array}{l}\text { High use of OA journals. The } \\
\text { major constraints are } \\
\text { unavailability of Internet facilities } \\
\text { and lack of knowledge of the } \\
\text { existence of OA journals. }\end{array}$ \\
\hline $\begin{array}{l}\text { Mammo and Ngulube, } \\
2013\end{array}$ & Ethiopia & $\begin{array}{l}\text { To examine knowledge, } \\
\text { use and attitudes } \\
\text { towards OA journals }\end{array}$ & 768 academics & $\begin{array}{l}\text { Mixed } \\
\text { methods }\end{array}$ & $\begin{array}{l}\text { Questionnaire } \\
\text { and interviews }\end{array}$ & $\begin{array}{l}\text { High levels of knowledge and use. } \\
\text { Positive attitudes towards OA } \\
\text { journals, but some confusion } \\
\text { about the issues regarding } \\
\text { copyright and impact factor. }\end{array}$ \\
\hline $\begin{array}{l}\text { Mischo and } \\
\text { Schlembach, } 2011\end{array}$ & US & $\begin{array}{l}\text { To examine faculty's OA } \\
\text { practices and attitudes }\end{array}$ & $\begin{array}{l}54 \text { engineering } \\
\text { faculty }\end{array}$ & $\begin{array}{l}\text { Mixed } \\
\text { methods }\end{array}$ & $\begin{array}{l}\text { Questionnaire } \\
\text { and interviews }\end{array}$ & $\begin{array}{l}\text { A vast majority never published in } \\
\text { OA journals and had limited plans } \\
\text { to do so in the future. Concerns } \\
\text { regarding the author-pays model. } \\
\text { An overwhelming consensus that } \\
\text { commercial publishers should not } \\
\text { pursue the Gold route. }\end{array}$ \\
\hline
\end{tabular}


Table 1

(Continued)

\begin{tabular}{|c|c|c|c|c|c|c|}
\hline Author(s) & Population & $\begin{array}{l}\text { Research } \\
\text { objectives }\end{array}$ & Participants & $\begin{array}{l}\text { Research } \\
\text { design }\end{array}$ & $\begin{array}{c}\text { Data collection } \\
\text { instrument }\end{array}$ & Main results \\
\hline $\begin{array}{l}\text { Nariani and Fernandez, } \\
2012\end{array}$ & Canada & $\begin{array}{l}\text { To study the uptake of } \\
\text { library support for } \\
\text { author funding, the } \\
\text { motivating factors and } \\
\text { satisfaction with OA } \\
\text { publishing }\end{array}$ & $\begin{array}{l}20 \text { faculty who } \\
\text { published in OA } \\
\text { journals }\end{array}$ & $\begin{array}{l}\text { Mixed } \\
\text { methods }\end{array}$ & $\begin{array}{l}\text { Questionnaire } \\
\text { and interviews }\end{array}$ & $\begin{array}{l}\text { Respondents were increasingly } \\
\text { publishing in OA journals and } \\
\text { were appreciative of library } \\
\text { funding initiatives. Impact factor } \\
\text { and readership were strong } \\
\text { motivators for publishing. }\end{array}$ \\
\hline $\begin{array}{l}\text { Nicholas, Huntington } \\
\text { and Rowlands, } 2005\end{array}$ & International & $\begin{array}{l}\text { To explore the author } \\
\text { views regarding OA } \\
\text { publishing }\end{array}$ & $\begin{array}{l}3,787 \text { authors } \\
\text { from } 97 \text { countries }\end{array}$ & Quantitative & Questionnaire & $\begin{array}{l}\text { General ignorance of OA } \\
\text { publishing. Differences in opinion } \\
\text { and practice between authors of } \\
\text { different disciplines and countries. }\end{array}$ \\
\hline Park and Qin, 2007 & US & $\begin{array}{l}\text { To explore motivating } \\
\text { factors for publishing in } \\
\text { an using OA journals }\end{array}$ & $\begin{array}{l}14 \text { faculty } \\
\text { members and } \\
\text { doctoral students }\end{array}$ & Qualitative & Interviews & $\begin{array}{l}\text { Perceived journal reputation, } \\
\text { topical relevance, and availability } \\
\text { are common incentives. Factors } \\
\text { affecting publishing and use are } \\
\text { interrelated. }\end{array}$ \\
\hline $\begin{array}{l}\text { Sanchez-Tarrago and } \\
\text { Fernandez-Molina, } 2009\end{array}$ & Cuba & $\begin{array}{l}\text { To assess knowledge } \\
\text { about and attitudes } \\
\text { towards the open access } \\
\text { movement }\end{array}$ & $\begin{array}{l}160 \text { researchers } \\
\text { from } 11 \text { health } \\
\text { institutions }\end{array}$ & Quantitative & Questionnaire & $\begin{array}{l}\text { Low level of knowledge and } \\
\text { unfamiliarity with OA initiatives } \\
\text { and strategies. Low rates of } \\
\text { publication in OA journals and } \\
\text { self-archiving. }\end{array}$ \\
\hline $\begin{array}{l}\text { Schroter, Tite and Smith, } \\
2005\end{array}$ & International & $\begin{array}{l}\text { To explore authors' } \\
\text { attitudes towards OA } \\
\text { publishing and author } \\
\text { charges }\end{array}$ & $\begin{array}{l}28 \text { international } \\
\text { authors } \\
\text { submitting to the } \\
\text { BMJ }\end{array}$ & Qualitative & Interviews & $\begin{array}{l}\text { Familiarity with OA. Low rates of } \\
\text { publication in OA journals other } \\
\text { than the BMJ. Positive attitudes } \\
\text { towards OA publishing. } \\
\text { Willingness to submit to OA } \\
\text { journals. Dislike for author } \\
\text { charges. }\end{array}$ \\
\hline
\end{tabular}


Table 1

(Continued)

\begin{tabular}{|c|c|c|c|c|c|c|}
\hline \multicolumn{7}{|c|}{ (Continued) } \\
\hline Author(s) & Population & $\begin{array}{l}\text { Research } \\
\text { objectives }\end{array}$ & Participants & $\begin{array}{c}\text { Research } \\
\text { design }\end{array}$ & $\begin{array}{c}\text { Data collection } \\
\text { instrument }\end{array}$ & Main results \\
\hline Schroter and Tite, 2006 & International & $\begin{array}{l}\text { To assess authors' } \\
\text { knowledge and } \\
\text { perceptions of OA } \\
\text { publishing }\end{array}$ & $\begin{array}{l}468 \text { international } \\
\text { authors } \\
\text { submitting to } \\
3 \text { biomedical } \\
\text { journals }\end{array}$ & Quantitative & Questionnaire & $\begin{array}{l}\text { Knowledge of OA publishing and } \\
\text { author-pays models. Low rates of } \\
\text { publication in author-pays } \\
\text { journals. OA policies had little } \\
\text { impact on authors' decision of } \\
\text { where to submit papers. }\end{array}$ \\
\hline Swan and Brown, 2004 & UK & $\begin{array}{l}\text { To compare opinions } \\
\text { and experiences of OA } \\
\text { authors and non-OA } \\
\text { authors }\end{array}$ & 311 authors & Quantitative & Questionnaire & $\begin{array}{l}\text { High awareness of OA publishing } \\
\text { opportunities. The main reason for } \\
\text { publishing in OA journals was the } \\
\text { principle of free access. The main } \\
\text { concerns were author charges and } \\
\text { impact. }\end{array}$ \\
\hline $\begin{array}{l}\text { Utulu and Bolarinwa, } \\
2009\end{array}$ & Nigeria & $\begin{array}{l}\text { To examine the extent of } \\
\text { academics' awareness } \\
\text { and use of OA initiatives } \\
\text { as authors and readers }\end{array}$ & $\begin{array}{l}180 \text { academic } \\
\text { staff members }\end{array}$ & Quantitative & Questionnaire & $\begin{array}{l}\text { High awareness of the pre-print } \\
\text { and open access journal initiatives } \\
\text { compared to the post-print } \\
\text { initiative. Significant use of OA } \\
\text { access initiatives. Differences in } \\
\text { awareness and attitudes between } \\
\text { disciplines. }\end{array}$ \\
\hline $\begin{array}{l}\text { Walrick and Vaughan, } \\
2007\end{array}$ & US & $\begin{array}{l}\text { To identify motivating } \\
\text { factors for publishing } \\
\text { and attitudes towards } \\
\text { OA }\end{array}$ & $\begin{array}{l}14 \text { biomedical } \\
\text { faculty }\end{array}$ & Quantitative & Interviews & $\begin{array}{l}\text { Publication quality, free access } \\
\text { and visibility were the most } \\
\text { important incentives for selection } \\
\text { of OA journals. }\end{array}$ \\
\hline
\end{tabular}


The same study revealed a relationship between publishing in OA and previous experience of publishing on the web. Scholars making available their materials on the web or depositing them in institutional repositories were more likely to publish in OA journals.

\subsection{Theme 2: Factors affecting decision to publish in OA journals}

The principle of free access for all readers emerged as an important motivation for publishing in OA journals. Open access articles reach a much larger audience than any priced journal and increased usage means increased visibility for authors, raising their profile and the impact of their research, and creating opportunities for international collaboration. As for the rest, scholars' decision to publish in OA venues is affected by the same factors determining journal choices in general. Of these, journal quality seems to be central to decision making and takes priority over the availability of open access.

As reported by some of the participants, requests for electronic copies of their publications by individual researchers, often in foreign countries, remains quite frequent and in some cases has prompted an interest in the open access movement. [21, p.12]

One faculty member [...] decided to publish in a BMC journal at the suggestion of her collaborators from a developing country. In another instance, a health science researcher, whose research has been focused on native communities in Ontario, wanted her paper to be read by aboriginal community researchers and hence decided to publish in an OA journal. The same author mentioned that she has started collaborating with researchers from Malaysia after reading their article in a BMC journal. [18, p. 187]

\subsection{Theme 3: Perceptions of $O A$ journals}

Clearly in the mind of most scholars the strongest characteristic of OA journals is that they promote improved and more equitable access to knowledge by all kinds of readers and availability of research papers to the developing world $[7,19,22,23,28]$. In a number of studies open access is perceived to facilitate wider diffusion of research outputs and increase the impact of researchers work [10,22,26,28].

Other benefits derived from open access are considered to be faster publication times [7,10,22,23, 28 ] and reduced costs, especially in terms of subscriptions to traditional journals, but also in terms of time savings, photocopying and interlibrary loans [7,24]. Swan and Brown observed differences in perceptions among OA journal authors and those who had not published in OA venues.

Over $90 \%$ of OA authors published in this way because of the principle of free access. They also associate other values with publishing in open access journals: they perceive them to be faster than traditional journals, to have a larger readership and consequently to be cited more frequently, and to have high prestige and quality than traditional journals available to them. The perceptions of NOA authors tend to be opposed: they perceive open access journals as having a smaller readership and lower citation rates, and of generally being of lower quality and prestige than the traditional journals they publish in. [16, p. 223]

Copyright ownership, which is perceived to give more control over authors' publications, has been reported as an advantage from the faculty members interviewed by Nariani and Fernandez [18]. As one 
researcher put it "I like OA journals because anyone can download these papers and I can use them as examples for teaching purposes. Students don't need to pay for it" (p. 189).

Besides perceived advantages, OA usually raises some concerns too. A number of studies have demonstrated that open access publications are often considered to be of low quality and consequently less respected and prestigious than established, subscription-based journals [7,11,19,24,26,28]. However, despite perceptions of poor quality, researchers believe that publishing in OA helps career development and should not be viewed as an obstacle to tenure and promotion $[18,19,28]$. Also, it appears that discussions about OA always bring up the issue of impact factor [26], and there is a belief that OA publications have lower impact factors than traditional journals or no impact factors at all, a problem discouraging many authors from publishing in such journals [24,28]. In addition, there is evidence that OA is mixed up with peer review, with many researchers assuming that OA journals have inferior peer review, something that might lead to vanity publishing [19,24].

\subsection{Theme 4: Author charges}

Views about author charges were found to vary, ranging from rejection to tolerance and even acceptance. Across several studies, respondents were mostly against author charges and would hesitate to submit to journals operating under the author-pays model $[11,23,24]$. The author-pays system is regarded as an additional barrier to researchers, and one that might reduce publishing opportunities, especially for underfunded or young researchers and researchers from the developing world [17,26]. The main concern of researchers seems to be how the fees will be paid, and support from grant agencies and institutions plays a significant role in shaping attitudes towards author charges. When funding agencies or universities cover the cost of publishing, author charges are not an issue $[18,24,28]$. In some instances respondents expressed concerns that author charges may deteriorate the review process $[7,17]$. There is also evidence that quality of the journal might alleviate the unwillingness of many authors to publish under an author-pays model [23,24].

\subsection{Theme 5: The role of the discipline}

Discipline appears to play a role in awareness of and attitudes towards OA journals. One of the most interesting findings of Nicholas, Huntington and Rowlands was that Science and Technology scholars were more likely to report knowing a lot about OA than their counterparts in Arts and Humanities who were more likely to report knowing nothing at all [19]. The authors attributed this difference to the fact that "scientists as a whole are more active in journal publishing and also in the frontline of OA developments" (p. 516). These findings are contradicted by a study conducted in Nigeria, which found that awareness of OA journals was higher among academics in the Humanities. In the same study, however, academics in Sciences showed increased willingness to adopt OA both as users and authors [27]. According to Gul, Shah and Baghwan Science scholars were more active in using and publishing in OA journals than their colleagues in Social Sciences. In the same study, Science scholars were found to be more familiar with OA content retrieval methods as compared to Social Science scholars.

Discipline has also an impact on how scholars view publication charges. Medical sciences authors seem to be less concerned with author fees, because many traditional, journals in these fields have long established pricing practices and charge authors without making their articles freely available. On the contrary, author publication fees are less common among social sciences publications. Moreover, funding for the Humanities and Social Sciences is generally less than that for Science, Engineering and Medicine, where researchers have more opportunities to get reimbursed for publication expenses. 


\section{Conclusion}

OA has and continues to change the ways of scientific research, literature search, journal editing, publishing, and archiving [9]. The aim of this work was to synthesize the results of previous studies concerning scholars' attitudes toward OA journals and provide an overview of OA from the point of view of current and potential authors. This meta- synthesis reveals that scholars hold positive views towards OA journals. It also indicates that, although academic researchers are aware of the fact that OA journals can bring many advantages in research visibility and impact, OA publishing is not yet fully understood neither has it reached its full potential. Although academics and authors appreciate the benefits of free dissemination of information and advocate the moral argument of unrestricted access to scientific research, they have some concerns about the author-pays model and they question the quality, reputation and impact of OA journals. The issue of journal prestige is of great importance for authors because, among other things, is closely related to tenure and promotion. Journal reputation and perceived quality seem to be more important factors considered by scholars when selecting a journal to publish in than whether it is open-access. In the past few years there has been an ongoing debate over the quality of OA journals, and a frequent criticism of OA is that it will threaten the peer-review system, diminishing the overall quality of scientific journal publishing. Recent research indicates that negative perceptions of the quality of OA publishing are not well grounded. A study comparing the scientific impact of OA journals with subscription journals showed that OA journals indexed in Web of Science and/or Scopus are approaching the same scientific impact and quality as subscription journals [5]. Similar conclusions have been drawn from a SOAP study, according to which "OA publishing is a mature field with similar patterns and quality indicators as non-OA publishing" [26, p. 13].

The other unfavorable aspect of OA journals is author-payment. Many scholars appear to think that OA journals charge authors. They are generally unwilling to pay author charges and requiring them to cover publication costs is a serious disincentive to OA publication, especially in fields where the vast amount of research is self-funded, funded by the author's home institution or the funding is too small. It is interesting that in almost all studies open access and author charges were considered as identical, even though many OA journals waive publication fees for authors who do not have access to grants and funding, and many authors have claimed that most OA journals do not charge authors for publication $[12,25]$. In fact, the majority of the journals listed in the Directory of OA Journals do not actually charge author-side fees but they rely on alternative sources of revenue [15]. The false assumption that all OA journals are fee-based adds to the misconceptions about open access and distorts the current OA publishing landscape.

The articles used in this meta-synthesis cover a time-span of twelve years. There is evidence that authors' understanding and practices concerning OA have changed over time. Rates of publication in OA journals and familiarity with OA publishing models seem to have increased. For example, there is a clear difference between the results reported nearly ten years ago by Nicholas, Huntington and Rowlands [19], and those reported in a very recent study by Nariani and Fernandez [18]. There is also evidence that the country differences observed by Nicholas, Huntington and Rowlands [19] continue to exist, with scholars in developing countries, like Ethiopia or Nigeria, demonstrating higher levels of OA journals knowledge and use.

Authors views should be taken into consideration by the key stakeholders of open access publishing. Attitudes and perceptions will determine the success and acceptance of this evolving model. Libraries can play an important role in connecting authors with OA movement by clarifying confusions, raising awareness of OA journals, and informing researchers of their publishing options. Librarians, who have 
long been calling for a change in the existing system, can communicate to both users and administrators the advantages of OA and its potential to address some of the problems surrounding the traditional publishing model.

One limitation of the present study is that it does not address all the issues associated with OA because the data are limited to the articles selected for inclusion. Another limitation has to do with the fact that quality assessment was not used for the exclusion of articles and so it is possible that some of the publications examined could be questioned for the quality of their methodology and the strengths of their findings.

\section{References}

[1] J. Allen, Interdisciplinary differences in attitudes towards deposit in institutional repositories, Education and Information Technologies (2005), available at: http://eprints.rclis.org/6957/1/FULLTEXT.pdf [Accessed 12 December 2013].

[2] R. Anderson, Author disincentives and open access, Serials Review 30 (2004), 288-291.

[3] C.R. Bair and J.G. Hawarth, Doctoral student attrition and persistence: a meta-synthesis of research, Higher Education: Handbook of Theory and Research 19 (2004), 481-534.

[4] B.-C. Bjork, Open access to scientific publications: an analysis of the barriers to change?, Information research 9 (2004), available at: http://InformationR.net/ir/9-2/paper170.html [Accessed 18 November 2013].

[5] B.-C. Bjork and D. Solomon, Open access versus subscription journals: a comparison of scientific impact, BMC Medicine 10 (2012), 73.

[6] Budapest Open Access Initiative, available at: http://www.soros.org/openaccess/read.html [Accessed 22 May 2008$].$

[7] B. Coonin, Open access publishing in business research: the authors' perspective, Journal of Business \& Finance Librarianship 16 (2004), 193-212.

[8] S. Dallmeier-Tiessen et al., The landscape of Open Access Publishing today, Talk presented at SOAP Symposium, 2011, available at: http://edoc.mpg.de/524966 [Accessed 2 March 2013].

[9] A.Y. Gasparyan, L. Ayvazyan and G.D. Kitas, Biomedical journal editing: elements of success, Croat. Med. J. 52 (2011), 423-428.

[10] S. Gul, T.A. Shah and T.A. Baghwan, Culture of open access in the University of Kashmir: a researcher's viewpoint, Aslib Proceedings: New Information Perspectives 62 (2010), 210-222.

[11] A.A. Hernandez-Borges, Awareness and attitude of Spanish medical authors to open access publishing and the 'author pays' model, Journal of Medical Library Association 94 (2006), 449-456.

[12] B. Hooker, If we won't sink in, maybe we can pound it in . .., Open Reading Frame, December, 2007, available at: http:// sennoma.net/?p=555 [Accessed 20 March 2014].

[13] O. Ivwighreghweta and O.K. Onoriode, Open access and scholarly publishing: opportunities and challenges to Nigerian researchers, Chinese Librarianship: an International Electronic Journal 33 (2012), available at: http://www.iclc.us/cliej/cl33IO.pdf [Accessed 18 November 2013].

[14] M. Kenneway, Author attitudes towards open access publishing, 2011, available at: http://www.intechopen.com/public files/Intech_OA_Apr11.pdf [Accessed 12 December 2013].

[15] M. Kozak and J. Hartley, Publication fees for open access journals: different disciplines - different methods, Journal of the American Society for Information Science and Technology 64 (2013), 2591-2594.

[16] Y. Mammo and P. Ngulube, Academics' use and attitude towards open access in selected higher learning institutions of Ethiopia, Information Development (2013), 1-14.

[17] W.H. Mischo and M.C. Schlembach, Open Access issues and engineering faculty attitudes and practices, Journal of Library Administration 51 (2011), 432-454.

[18] R. Nariani and L. Fernandez, Open access publishing: what authors want, College \& Research Libraries 73 (2012), 182195.

[19] D. Nicholas, P. Huntington and I. Rowlands, Open access journal publishing: the views of some of the world's senior authors, Journal of Documentation 61 (2005), 497-519.

[20] K.L. Palmer, E. Dill and C. Christie, Where there's a will there's a way? Survey of academic librarian attitudes about open access, College \& Research Libraries 70 (2009), 315-335.

[21] J.H. Park and J. Qin, Exploring the willingness of scholars to accept open access: a grounded theory approach, Journal of Scholarly Publishing 38 (2007), 55-84.

[22] N. Sanchez-Tarrago and J.C. Fernandez-Molina, The open access movement and Cuban health research work: an author survey, Health Information and Libraries Journal 27 (2009), 6-74. 
[23] S. Schroter and L. Tite, Open access publishing and author-pays business models: a survey of authors' knowledge and perceptions, Journal of The Royal Society of Medicine 99 (2006), 141-148.

[24] S. Schroter, L. Tite and R. Smith, Perceptions of open access publishing: interviews with journal authors, BMJ (2005), available at: http://www.bmj.com/content/330/7494/756 [Accessed 18 November 2013].

[25] S. Shieber, What percentage of open-access journals charge publication fees?, The Occasional Pamphlet, May 2009, available at: http://blogs.law.harvard.edu/pamphlet/2009/05/29/what-percentage-of-open-access-journals-chargepublication-fees/ [Accessed 20 March 2014].

[26] A. Swan and S. Brown, Authors and open access publishing, Learned Publishing 17 (2004), 21-224.

[27] S.C.A. Utulu and O. Bolarinwa, Open access initiatives adoption by Nigerian academics, Library Review 58 (2009), 660-669.

[28] S.E. Warlick and K.T.L. Vaughan, Factors influencing publication choice: why faculty choose open access, Biomedical Digital Libraries 4 (2007), available at: http://www.bio-diglib.com/content/4/1/1 [Accessed 18 November 2013]. 